\title{
PERAN KOMPONEN CINTA PADA SIKAP TERHADAP HUBUNGAN SEKSUAL PRANIKAH REMAJA AKHIR YANG BERPACARAN DI KABUPATEN BANGLI Chitta Dhyana Premaswari, Made Diah Lestari
}

Program Studi Psikologi, Fakultas Kedokteran, Universitas Udayana chittadhyana@gmail.com

\begin{abstract}
Abstrak
Sikap terhadap hubungan seksual pranikah adalah serangkaian evaluasi dan respon individu yang meliputi kognitif, afektif, dan konatif yang menggambarkan sejauhmana individu menerima atau setuju dan menolak atau tidak setuju terhadap hubungan seksual yang dilakukan pasangan yang belum terikat tali pernikahan. Sikap terhadap hubungan seksual pranikah dipengaruhi oleh faktor cinta yang terdiri dari komponen intimacy, passion, dan commitment. Penelitian ini bertujuan untuk melihat peran komponen cinta (intimacy, passion, commitment) pada sikap terhadap hubungan seksual pranikah remaja akhir yang berpacaran di Kabupaten Bangli. Subjek penelitian ini adalah remaja akhir di Kabupaten Bangli yang memiliki pacar dan berusia 18-22 tahun sejumlah 115 orang subjek. Teknik pengambilan sampel menggunakan two stage cluster sampling. Hasil yang diperoleh dari analisis regresi berganda menunjukkan nilai $\mathrm{R} 2=0,359$ ( $\mathrm{p}<0,05)$, hal ini berarti bahwa intimacy, passion, commitment secara bersama-sama berperan sebesar 35,9\% dalam menjelaskan sikap terhadap hubungan seksual pranikah. Koefisien beta terstandarisasi intimacy sebesar $-0,138$ dan signifikansi $0,227(p>0,05)$ menunjukkan bahwa intimacy tidak berperan pada sikap terhadap hubungan seksual pranikah. Koefisien beta terstandarisasi passion sebesar 0,787 dan signifikansi 0,000 $(\mathrm{p}<0,05)$ menunjukkan bahwa passion berperan pada sikap terhadap hubungan seksual pranikah. Koefisien beta terstandarisasi commitment sebesar -0,213 dan signifikansi 0,080 ( $>00,05)$ menunjukkan bahwa commitment tidak berperan pada sikap terhadap hubungan seksual pranikah. Hal ini menunjukkan bahwa hanya komponen passion yang berperan secara parsial pada sikap terhadap hubungan seksual pranikah remaja akhir yang berpacaran di Kabupaten Bangli.
\end{abstract}

Kata kunci: sikap terhadap hubungan seksual pranikah, intimacy, passion, commitment, remaja akhir yang berpacaran

\begin{abstract}
Attitudes toward premarital sexual relations are a series of evaluations and the individual response that includes cognitive, affective, and conative responses which indicate how far individuals accept or agree and refuse or disagree to premarital sexual relations. Attitudes toward premarital sexual relations are influenced by the factor of love that consists of components intimacy, passion, and commitment, which called triangle of love. This study aimed to analyzedthe role of the components of love (intimacy, passion, commitment) on attitudes toward premarital sexual relationof the dating late adolescentsfound in the Bangli Regency. The research subjectswere the late adolescents in Bangli Regencywho were dating, and aged 18-22 years old of 115 subjects. The sampling technique used a two stage cluster sampling. The results of multiple regression analysis showed the score of $\mathrm{R} 2=0.359(\mathrm{p}<0.05)$, this means that intimacy, passion, and commitment jointly contribute by $35.9 \%$ in explaining the attitudes toward premarital sexual relations. The intimacy standardized beta coefficient of -0.138 and significance of $0.227(\mathrm{p}>0.05)$ showed that intimacy did not play a significant role in the attitudes toward premarital sexual relations. The passion standardized beta coefficient of 0.787 and a significance of $0.000(\mathrm{p}<0.05)$ showed that the passion plays a significant role in attitudes toward premarital sexual relations. The commitment standardized beta coefficient of -0.213 and significance of $0.080(p>0.05)$ showed that the commitment did not play a significant role in attitudes toward premarital sexual relations. These indicate that only the component of passion that contributespartially tothe attitudes toward premarital sexual relations of the dating late adolescents in the BangliRegency.
\end{abstract}

Keywords:attitudes toward premarital sexual relations, intimacy, passion, commitment,

dating late adolescents 


\section{LATAR BELAKANG}

Remaja diartikan sebagai masa peralihan dari masa kanak-kanak menuju masa dewasa dan terjadi perubahan dalam diri remaja yang mencakup perubahan biologis, kognitif, dan sosial emosional (Santrock, 2007). Masa remaja merupakan periode kritis dan masa topan badai, yaitu masa saat terjadi perubahan yang signifikan secara fisik, intelektual dan emosional pada diri remaja yang dapat menimbulkan konflik dengan diri sendiri dan dengan lingkungannya (Hall dalam Seifert \& Hoffnung, 1987). Papalia, Olds dan Feldman (2009) menjelaskan rentang usia remaja terbagi dalam dua tahap yakni masa remaja awal yang berlangsung sekitar usia 11 tahun atau 12 tahun hingga usia 14 tahun dan masa remaja akhir yang berlangsung sekitar usia 15 tahun hingga 20 tahun.

Perjalanan hidup seorang remaja tidak selamanya berjalan dengan mulus, seorang remaja dihadapkan pada berbagai pilihan dalam hidup yang dapat memengaruhi hidupnya di masa depan. Perkembangan yang dialami di masa remaja pada hakikatnya merupakan suatu usaha penyesuaian diri saat mereka secara aktif mengatasi stres dan mencari jalan keluar baru dari berbagai masalah yang dihadapinya (Bloss dalam Sarwono, 2013). Ketika mereka tidak mampu memahami dengan benar cara menghadapi dan melewati masa penyesuaian diri tersebut, maka akan ada banyak penyimpangan perilaku yang dapat terjadi pada remaja dan dapat menurunkan kualitas dari remaja itu sendiri. Salah satu faktor yang dapat menghambat upaya peningkatan kualitas remaja adalah masalah yang berkaitan dengan kesehatan reproduksi remaja.

Berdasarkan informasi dan berbagai laporan dinyatakan banyak remaja sudah terjebak dalam perilaku reproduksi tidak sehat, diantaranya hubungan seksual yang dilakukan oleh remaja sebelum menikah (Soetjiningsih, 2008). Para remaja memiliki rasa ingin tahu yang sangat tinggi dan tidak ada habisnya terhadap hal-hal yang berkaitan dengan permasalahan seksual (Santrock, 2007). Masalah yang terkait dengan perilaku seksual paling sering terjadi pada kelompok usia remaja. Salah satu penyebab timbulnya masalah ini adalah karena adanya suatu perubahan bentuk fisik maupun psikologis pada remaja (Yunita, 2006). Bentuk perkembangan yang menonjol pada masa remaja yaitu terjadi perubahanperubahan fisik yang memengaruhi pola perkembangan kehidupan seksualnya (Soejoeti, 2001). Hal tersebut ditandai dengan mulai matangnya organ seksual baik primer maupun sekunder sehingga minat seks pada remaja mulai meningkat. Secara psikologis, perubahan yang terjadi pada masa remaja yaitu munculnya dorongan seksual, perasaan cinta dan perasaan tertarik terhadap lawan jenis sehingga hal tersebut juga dapat memengaruhi peningkatan minat seks pada remaja (Soejoeti, 2001).
Seiring dengan perkembangan zaman, terdapat pergeseran nilai pada masyarakat terutama remaja terkait permasalahan seks pranikah. Pergeseran nilai tersebut tercermin pada sikap remaja dalam menanggapi masalah hubungan seksual pranikah di kalangan remaja yang berpacaran. Terjadi berbagai perubahan terkait pola pikir (kognitif), perasaan (afektif), hingga tingkah laku (konatif) pada remaja yang menimbulkan pergeseran nilai-nilai yang dianut. Ada pro dan kontra yang timbul di masyarakat, terutama pada remaja itu sendiri terkait dengan sikap mereka terhadap permasalahan seks pranikah di kalangan remaja yang berpacaran. Sikap remaja saat ini terhadap hubungan seksual pranikah telah mengalami pergeseran nilai (Prihartini, Nuryoto \& Aviatin, 2002). Hal tersebut disebabkan oleh adanya perubahan dalam hal budaya dan gaya hidup di masyarakat. Remaja saat ini cenderung bersikap lebih permisif terhadap hubungan seksual pranikah.

Terkait dengan sikap, ketika remaja akan mengambil suatu keputusan dan tindakan maka remaja semestinya mempertimbangkan hasil dan konsekuensinya terlebih dahulu. Dalam mengukur sikap, maka harus mencakup tiga komponen sikap, diantaranya komponen kognitif, afektif dan konatif (Azwar, 2007). Sikap menjadi salah satu faktor predisposisi dalam teori Green dan Krauter (1991) yang berperan dalam pembentukan perilaku seseorang (Arde, 2011). Teori perilaku klasik menjelaskan bahwa sikap yang positif akan menyebabkan perilaku yang positif juga (Damayanti, 2007). Menurut Faturochman (1992), berdasarkan kajian dari berbagai literatur berupa hasil penelitian dan textbook, disimpulkan bahwa perilaku seksual pranikah sangat berkaitan dengan sikap permisif terhadap hubungan seksual pranikah.

Hasil survei rencana pembangunan jangka menengah nasional remaja yang dilakukan oleh BKKBN pada tahun 2010 hingga 2012 yang kemudian data tersebut dianalisis oleh Robi'ie (2013), menghasilkan bahwa sikap remaja di Indonesia terhadap hubungan seksual pranikah sebagian besar adalah tidak setuju. Pada tahun 2010, sebanyak 14.772 remaja atau sekitar 90,4\% menyatakan tidak setuju terhadap hubungan seksual pranikah, kemudian pada tahun 2011 sebanyak 13.025 atau sekitar $88,7 \%$ dan tahun 2012 sebanyak 13.496 remaja atau sekitar $93,0 \%$. Remaja yang setuju atau bersikap positif terhadap hubungan seksual pranikah persentasenya adalah sebesar 9,6\% pada tahun $2010,11,3 \%$ pada tahun 2011 dan 7,0\% pada tahun 2012 .

Remaja yang belum menikah belum diperbolehkan untuk melakukan aktivitas seksual yang berisiko tinggi seperti hubungan seksual pranikah. Hal itu dikarenakan dampak yang ditimbulkan dari aktivitas seksual dapat mengakibatkan berbagai masalah, misalnya masalah psikologis, hamil pranikah atau disebut dengan kehamilan yang tak diinginkan 
(KTD), aborsi, infeksi menular seksual (IMS) dan HIV-AIDS (Syamsulhuda, Musthofa \& Winarti, 2010). Angka KTD yang terjadi di Indonesia masih tergolong cukup tinggi. Data WHO mencatat lebih dari 32.000 perempuan mengalami KTD dalam rentang waktu antara tahun 2010 hingga 2014. Jumlah tersebut menjadi salah satu yang paling tinggi di kawasan ASEAN (Tribunnews.com, 2015). Di Indonesia, kasus KTD semakin banyak ditemui di Provinsi Bali (Kompas.com, 2009). Berdasarkan data dari BKKBN tahun 2006, tingkat KTD di Bali dari tahun 2002-2006 mencapai 18.582 kasus.

Berdasarkan data dari Dinas Kependudukan dan Catatan Sipil, pada tahun 2010 jumlah remaja di Bali sebanyak 597.667 ribu jiwa dan selalu mengalami peningkatan setiap tahunnya. Data dari KISARA (dalam Natalia, 2013) menunjukkan bahwa jumlah kasus KTD di Bali mencapai 500 kasus selama September 2008 hingga September 2009 atau rata-rata 41 kasus dalam satu bulannya. Hasil survei yang dilakukan oleh Survei Demografi dan Kesehatan Indonesia (SDKI) dan Survei Sosial Ekonomi Nasional (Susenas) pada tahun 2012 mengenaikasus remaja yang melahirkan berdasarkan kabupaten/kota di Bali menunjukkan bahwa Kabupaten Bangli menempati peringkat pertama dengan 86 kasus dari 1000 kelahiran. Di peringkat kedua adalah Kabupaten Karangasem dengan 57 kasus dari 1000 kelahiran dan di peringkat ketiga yaitu Kabupaten Buleleng dengan 53 kasus dari 1000 kelahiran. Berdasarkan data diatas, maka isu mengenai seks pranikah pada remaja masih sangat relevan untuk diteliti terutama pada Kabupaten Bangli. Hal tersebutkarena melihat data kasus remaja di Bali yang telah melahirkan menunjukkan angka tertinggi pada Kabupaten Bangli.

Fenomena perilaku remaja saat ini ketika berpacaran sudah tidak sehat. Atas dasar rasa ketertarikan fisik dan dorongan seksual terhadap pasangan, perilaku remaja mulai diarahkan untuk menarik perhatian pasangan. Remaja dalam berpacaran akan melibatkan aspek emosi yang diekspresikan dalam bentuk perilaku yang menuntut keintiman secara fisik dengan pasangannya, seperti bergandengan tangan, berpelukan, berciuman hingga melakukan hubungan seksual dengan pasangan (Taufik \& Anganthi, N.R.N, 2005).

Salah satu faktor yang dapat mendorong remaja untuk melakukan hubungan seksual pranikah disebabkan karena remaja mempunyai persepsi bahwa hubungan seksual menjadi sebuah cara untuk mengungkapkan dan mengekspresikan cinta, sehingga demi cinta, individu rela untuk melakukan hubungan seksual dengan pasangannya sebelum menikah (Setyawan 2004). Secara psikologis, cinta adalah sebuah perilaku manusia secara emosional yang wujudnya adalah tanggapan atau reaksi emosional individu terhadap rangsangan tertentu (Faiz, 2002). Psikologi sebagai ilmu yang mempelajari manusia didalamnya juga membahas mengenai konsep cinta karena hanya manusia yang dapat merasakan cinta (Tambunan, 2001).

Berdasarkan Sternberg's triangular theory of love(teori segitiga cinta Sternberg), cinta memiliki tiga komponen utama yaitu intimacy (keintiman) mencakup perasaan dekat, terkait, dan terikat dalam hubungan, rasa kagum dan ingin memberi perhatian pada pasangan; passion (gairah) yang mengarah pada dorongan yang menimbulkan emosi kuat dalam hubungan cinta seperti ketertarikan fisik dan hubungan seksual, serta komponen terakhir yaitu commitment(komitmen) yang merupakan keputusan untuk mencintai orang lain, dalam konteks jangka pendek dan komitmen untuk menjaga cinta itu, dalam konteks jangka panjang (Sternberg dalam Taylor, 2009). Dengan terpenuhinya ketiga komponen cinta tersebut secara seimbang dan membentuk suatu segitiga sama sisi, maka akan terbentuk sebuah cinta yang sempurna (Sternberg, 1998).

Berdasarkan komponen pembentuk cinta yang dikemukakan oleh Sternberg (1998), ketiga komponen tersebut dapat memiliki peranan dalam memunculkan perilaku individu terhadap pasangannya yang identik dengan pemenuhan kebutuhan seksual. Intimacy merupakan faktor kedekatan dalam suatu hubungan (Sternberg, 1998). Intimacy berkaitan dengan kebersamaan, keterikatan, dan hubungan emosional dengan orang lain (Lehmiller, 2014). Intimacy merupakan perasaan keterikatan dalam suatu hubungan, maka dengan adanya perasaan dekat dan terikat terhadap pasangan ketika menjalani hubungan bersama dapat mendorong mereka untuk melakukan suatu aktivitas seksual yang dapat mengarah pada aktivitas hubungan seksual karena setiap pasangan merasakan hubungan yang hangat, ingin selalu berada di dekat pasangannya, serta bersediamelakukan dan memberikan apapun untuk membuktikan cinta mereka. Adanya keterikatan dan hubungan emosional yang kuat dengan pasangan dapat mendorong remaja untuk melakukan hubungan seksual pranikah dengan pasangannya sehingga hal tersebut dapat membentuk sikap yang positif terhadap hubungan seksual pranikah pada remaja. Remaja yang sedang dalam periode ingin tahu dan ingin mencoba akan dengan mudah terjerumus dalam hubungan yang mengarah pada hubungan seksual dengan pasangannya karena mereka pada umumnya belum pernah mengetahui masalah seksual secara lengkap (Sarwono, 2013).

Passion berkaitan dengan ketertarikan fisik dan dorongan seksual atau libido (Lehmiller, 2014). Passion yang dimiliki oleh setiap pasangan dalam suatu hubungan akan meningkatkan keinginan besar dari dalam diri setiap individu untuk selalu mencintai pasangan mereka.Dalam kebanyakan hubungan cinta, kebutuhan seksual menjadi bagian utama dari 
gairah. Adanya passion yang besar dalam hubungan berpasangan akan meningkatkan hasrat untuk mendorong individu dalam melakukan aktivitas seksual. Adanya libido yang dapat menimbulkan hasrat seksual pada individu membutuhkan penyaluran dalam bentuk aktivitas seksual tertentu (Sarwono, 2013). Remaja dengan passion yang tinggi dalam sebuah hubungan akan cenderung untuk melakukan aktivitas seksual yang mengarah pada hubungan seksual sehingga remaja tersebut akan memiliki sikap yang positif terhadap hubungan seksual pranikah. Hal tersebut terutama terjadi pada remaja karena pada masa remaja terjadi perubahan-perubahan hormonal yang meningkatkan hasrat seksual (libido seksualitas) dan peningkatan hasrat seksual ini membutuhkan penyaluran dalam bentuk tingkah laku seksual tertentu (Sarwono, 2013).

Commitment merupakan keputusan untuk mencintai pasangan dan menjaga cinta mereka agar tercipta hubungan yang harmonis. Commitment sering diartikan sebagai keputusan untuk tetap bersama dengan pasangan dalam hidupnya. Kedua pihak saling memperhatikan kebutuhan satu sama lain dan harus meletakkan kebutuhan pasangan sebagai prioritas utama, termasuk kerelaan untuk berkorban secara pribadi demi terciptanya hubungan yang baik. Bila memutuskan untuk berkomitmen, individu harus bisa menerima pasangan tanpa syarat, memikirkan pasangan sepanjang waktu, dan melakukan sesuatu demi pasangan (Achmanto dalam Marasabessy, 2009). Remaja yang berpacaran dengan komitmen hubungan yang tinggi berorientasi pada hubungan jangka panjang yang akan berlanjut ke pernikahan. Individu akan memilikikepercayaan sepenuhnya terhadap pasangannya untuk saling setia. Adanya rasa kepercayaanyang dimiliki oleh setiap pasangan mendorong pasangan yang saling berkomitmen untuk menunjukkan rasa cinta dan sayang mereka dengan melakukan aktivitas seksual yang dapat mengarah pada hubungan seksual karena setiap pasangan akan berpikir bahwa tidak ada yang perlu dikhawatirkan ketika mereka melakukan hubungan seksual pranikah karena keyakinan bahwa pasangannya saat ini akan menjadi pasangan hidupnya nanti. Hal tersebut dapat membentuk sikap yang positif terhadap hubungan seksual pranikah pada remaja. Commitment berkaitan dengan keputusan untuk membina hubungan jangka panjang dan keputusan untuk tetap menjaga cinta itu (Sternberg, 1998).

Bentuk, kuantitas, serta kualitas dari komponen intimacy, passion, dan commitment pada setiap pasangan dalam sebuah hubungan tentu akan berbeda-beda. Remaja yang telah melakukan beragam bentuk aktivitas seksual hingga sexual intercourse dilatarbelakangi oleh komponen pembentuk cinta yang berbeda-beda pada pasangannya dan itulah yang menyebabkan mereka bersedia melakukan hal tersebut. Seperti yang telah dipaparkan sebelumnya, intimacy, passion, dan commitment berkontribusi pada sikap terhadap hubungan seksual pranikah.Berdasarkan fenomena hubungan seksual pranikah yang semakin meningkat di kalangan remaja, penelitian ini mencoba untuk mengidentifikasikan peran komponen pembentuk cinta (intimacy, passion, commitment) pada sikap terhadap hubungan seksual pranikah di kalangan remaja yang berpacaran.

Berdasarkan pada permasalahan yang telah dipaparkan, penelitian ini ingin melihat bagaimanakah peran dari intimacy, passion, dan commitment pada sikap terhadap hubungan seksual pranikah remaja akhir yang berpacaran di Kabupaten Bangli. Penelitian ini bertujuan untuk mengetahui peran dari intimacy, passion, dan commitment pada sikap terhadap hubungan seksual pranikah remaja akhir yang berpacaran di Kabupaten Bangli.

Hipotesis penelitian ini terdiri dari hipotesis mayor yaitu komponen cinta berperan pada sikap terhadap hubungan seksual pranikah remaja akhir yang berpacaran di Kabupaten Bangli dan hipotesis minor diantaranya intimacy berperan pada sikap terhadap hubungan seksual pranikah remaja akhir yang berpacaran di Kabupaten Bangli, passion berperan pada sikap terhadap hubungan seksual pranikah remaja akhir yang berpacaran di Kabupaten Bangli, commitment berperan pada sikap terhadap hubungan seksual pranikah remaja akhir yang berpacaran di Kabupaten Bangli.

\section{METODE PENELITIAN}

\section{Variabel dan definisi operasional}

Variabel bebas dalam penelitian ini adalah komponen cinta yang terdiri dari komponen intimacy, passion dan commitment. Variabel tergantung dalam penelitian ini adalah sikap terhadap hubungan seksual pranikah.

Definisi operasional dari masing-masing variabel dalam penelitian ini adalah sebagai berikut:

1. Sikap terhadap hubungan seksual pranikah

Sikap terhadap hubungan seksual pranikah adalah serangkaian evaluasi dan respon individu yang meliputi kognitif, afektif, dan konatif yang menggambarkan sejauhmana individu menerima atau setuju dan menolak atau tidak setuju terhadap hubungan seksual yang dilakukan pasangan yang belum terikat tali pernikahan atau belum resmi menjadi sepasang suami istri, dan kemudian akan menghasilkan respon positif (favorable) dan negatif (unfavorable) terhadap objek tersebut.Sikap terhadap hubungan seksual pranikah diukur berdasarkan komponen sikap yang dikemukakan oleh Azwar (2007), yang terdiri dari komponen kognitif, komponen afektif dan komponen perilaku (konatif). Semakin tinggi skor total, 
maka semakin positif taraf sikap terhadap hubungan seksual pranikah pada subjek.

2. Komponen cinta

Cintaterdiri dari tiga komponen utama yaitu intimacy, passion dan commitment yang disebut sebagai teori segitiga cinta Sternberg(Taylor, 2009).

a. Intimacy

Intimacy merupakan perasaan dekat, hangat, terhubung dan adanya kelekatan antar individu dalam sebuah hubungan yang dapat muncul dari hubungan pertemanan jangka panjang serta dapat membuat pasangan dalam suatu hubungan saling berbagi pikiran dan perasaan mereka yang terdalam. Taraf intimacy diukur dengan skala komponen cinta yang diadaptasi dari Sternberg (1998). Skor total aitem yang diperoleh menunjukkan seberapa tinggi kadar intimacy dalam pembentukan sikap terhadap hubungan seksual pranikah pada subjek, semakin tinggi skor total maka semakin tinggi kadar intimacy.

\section{b. Passion}

Passion merupakan suatu dorongan yang mengarah pada hubungan yang romantis serta ketertarikan terhadap suatu aktivitas dalam sebuah hubungan yang dianggap sebagai hal yang penting sehingga merelakan untuk melakukan apapun untuk aktivitas tersebut. Taraf passion diukur dengan skala komponen cinta yang diadaptasi dari Sternberg (1998). Skor total aitem yang diperoleh menunjukkan seberapa tinggi kadar passion dalam pembentukan sikap terhadap hubungan seksual pranikah pada subjek, semakin tinggi skor total maka kadar passion akan semakin tinggi.

\section{c. Commitment}

Commitment adalah suatu keputusan untuk mencintai pasangan dan menjaga sebuah hubungan tetap utuh yang ditandai dengan adanya kekuatan dalam suatu hubungan untuk dapat mempertahankan hubungan tersebut. Taraf commitment diukur dengan skala komponen cinta yang diadaptasi dari Sternberg (1998). Skor total aitem yang diperoleh menunjukkan seberapa tinggi kadar commitment dalam pembentukan sikap terhadap hubungan seksual pranikah pada subjek, semakin tinggi skor total maka semakin tinggi kadar commitment.

\section{Responden}

Populasi dalam penelitian ini adalah remaja akhir yang berpacaran di Kabupaten Bangli. Karakteristik populasi yang digunakan dalam penelitian ini yaitu remaja yang berdomisili di wilayah Bangli dengan usia 18-22 tahun, berjenis kelamin laki-laki dan perempuan serta berstatus sedang berpacaran.

Teknik pengambilan sampel menggunakan two stage cluster sampling. Pada proses pengambilan data, jumlah skala yang tersebar sebanyak 180 skala, namun hanya 115 skala yang memenuhi syarat kelengkapan untuk dapat dilakukan analisis data.

\section{Tempat penelitian}

Penelitian dilakukan di beberapa sekolah dan Sekolah Tinggi/Perguruan Tinggi yang berada di Kecamatan Bangli dan telah terpilih melalui undian secara random. Pengambilan data dilakukan pada tanggal 26 Mei 2016 di SMAN 1 Bangli, pada tanggal 27 Mei 2016 di IHDN Denpasar (Kampus Bangli) dan STKIP Suar Bangli, pada tanggal 28 Mei 2016 di SMKN 1 Bangli serta pada tanggal 3 Juni 2016 di Kampus Mediterranean Bali (Kampus Bangli).

\section{Alat ukur}

Alat ukur yang digunakan dalam penelitian ini menggunakan dua buah skala. Skala pertama merupakan skala yang mengukur sikap terhadap hubungan seksual pranikah dan skala kedua adalah skala yang mengukur komponen cinta. Skala sikap terhadap hubungan seksual pranikah disusun sendiri oleh peneliti dengan mengacu pada aspek sikap oleh Azwar (2007), dan skala komponen cinta diadaptasi dari skala komponen cinta Sternberg (1998).

Skala sikap terhadap hubungan seksual pranikah terdiri dari 48 aitem pernyataan yang disajikan dalam bentuk skala likert yang terdiri dari empat pilihan jawaban yaitu Sangat Setuju (SS), Setuju (S), Tidak Setuju (TS) dan Sangat Tidak Setuju (STS), dan pernyataan terbagi dalam kalimat positif (favorable) dan kalimat negatif (unfavorable).

Skala komponen cinta terdiri dari 45 aitem pernyataan yang terbagi kedalam aitem nomor 1-15 untuk mengukur komponen intimacy, aitem nomor 16-30 untuk mengukur komponen passion, dan aitem nomor 31-45 untuk mengukur komponen commitment. Skala ini disajikan dalam bentuk skala likert yang terdiri dari sembilan rentang pilihan jawaban dari angka 1-9, dengan angka 1 yang berarti sangat tidak setuju, 5 berarti sedang, dan 9 yang berarti sangat setuju. Skala disajikan dalam bentuk pernyataan kalimat positif (favorable).

Pada penelitian ini dilakukan serangkaian uji validitas dan reliabilitas alat ukur. Uji validitas dilakukan dengan teknik professionaljudgement dan dengan pengujian konsistensi aitem total melalui corrected item total correlation. Kriteria pemilihan aitem berdasarkan korelasi aitem total yaitu dengan melihat nilai $r_{i x} \geq 0,30$. Aitem-aitem yang mencapai koefisien korelasi lebih besar atau sama dengan 0,30 maka daya bedanya dianggap memuaskan. Aitem-aitem yang memiliki koefisien korelasi kurang dari 0,30 dapat dikategorikan sebagai aitem yang memiliki daya beda rendah (Azwar, 2014). 
Uji reliabilitas alat ukur dilakukan dengan formulasi cronbach's alpha. Suatu alat ukur dianggap reliabel jika koefisien alphanya mencapai minimal 0,80 (Azwar, 2013).

Pelaksanaan uji coba alat ukur berlangsung selama empat hari yaitu pada tanggal 28 April, 29 April, 2 Mei dan 3 Mei 2016. Pada tahap uji coba alat ukur penelitian, kuesioner yang tersebar sebanyak 70 buah namun kuesioner yang memenuhi syarat untuk dapat dianalisa sebanyak 69 buah.

Hasil uji validitas pada skala sikap terhadap hubungan seksual pranikah menunjukkan nilai koefisien korelasi aitem total berkisar antara 0,339-0,743. Hasil uji reliabilitas pada skala sikap terhadap hubungan seksual pranikah menghasilkan koefisien alpha $(\alpha)$ sebesar 0,960, yang berarti bahwa skala sikap terhadap hubungan seksual pranikah mampu mencerminkan sebesar $96,0 \%$ variasi yang terjadi pada skor murni subyek. Hasil uji reliabilitas yang diperoleh menunjukkan bahwa skala sikap terhadap hubungan seksual pranikah dapat digunakan untuk mengukur sikap terhadap hubungan seksual pranikah pada subjek penelitian.

Hasil uji validitas pada skala komponen cinta yang terdiri dari 15 aitem komponen intimacy, 15 aitem komponen passion dan 15 aitem komponen commitment menunjukkan pada komponen intimacy, nilai koefisien korelasi aitem total berkisar antara 0,473-0,834. Pada komponen passion, nilai koefisien korelasi aitem total berkisar antara 0,499-0,745. Pada komponen commitment, nilai koefisien korelasi aitem total berkisar antara 0,626-0,905. Hasil uji reliabilitas pada skala komponen cinta yang terdiri dari komponen intimacy, passion dan commitment, pada komponen intimacy, menghasilkan koefisien alpha $(\alpha)$ sebesar 0,921. Hal ini menunjukkan bahwa komponen intimacy mampu mencerminkan sebesar $92,1 \%$ variasi yang terjadi pada skor murni subyek. Pada komponen passion, menghasilkan koefisien alpha $(\alpha)$ sebesar 0,933 . Hal ini menunjukkan bahwa komponen passion mampu mencerminkan sebesar 93,3\% variasi yang terjadi pada skor murni subyek. Pada komponen commitment, menghasilkan koefisien alpha $(\alpha)$ sebesar 0,960. Hal ini menunjukkan bahwa komponen commitment mampu mencerminkan sebesar $96,0 \%$ variasi yang terjadi pada skor murni subyek. Hasil uji reliabilitas yang diperoleh menunjukkan bahwa skala komponen cinta yang teridiri dari komponen intimacy, passion dan commitment dapat digunakan untuk mengukur komponen cinta pada subjek penelitian.

\section{Teknik analisis data}

Sebelum melakukan analisis data dan untuk memastikan data penelitian yang telah diperoleh dapat diolah, maka dilakukan uji asumsi yang terdiri dari uji normalitas, uji linearitas dan uji multikolinearitas. Uji normalitas pada penelitian ini menggunakan uji Kolmogorov-Smirnov. Uji linearitas menggunakan teknik comparemeans dengan melihat nilai testoflinearity.Uji multikolinearitas dilakukan dengan melihat nilai Variance Inflation Factor (VIF) dan Tolerance. Setelah melakukan uji asumsi, data penelitian dianalisis dengan menggunakan metode analisis regresi berganda untuk pembuktian hipotesis mayor dan hipotesis minor. Analisis data dilakukan dengan menggunakan bantuan perangkat lunak Statistical Package for Social Service (SPSS) 17.0 for windows.

\section{HASIL PENELITIAN}

\section{Karakteristik subjek}

Berdasarkan data karakteristik subjek diperoleh bahwa total subjek berjumlah 115 orang yang terdiri dari 56 orang laki-laki dengan persentase sebesar $48,7 \%$ dan 59 orang perempuan dengan persentase sebesar 51,3\%. Mayoritas subjek dalam penelitian ini berada pada usia 21 tahun yaitu sejumlah 27 orang dengan persentase sebesar $23,5 \%$.

\section{Deskripsi data penelitian}

Hasil deskripsi data penelitian variabel sikap terhadap hubungan seksual pranikah, intimacy, passion, dan commitment dapat dilihat pada tabel 1 .

\begin{tabular}{|c|c|c|c|c|c|c|c|}
\hline Variabel & $\mathrm{N}$ & $\begin{array}{l}\text { Mean } \\
\text { Teoretis }\end{array}$ & $\begin{array}{l}\text { Mean } \\
\text { Empiris }\end{array}$ & $\begin{array}{l}\text { Std. } \\
\text { Deviasi } \\
\text { Teoretis }\end{array}$ & $\begin{array}{l}\text { Std. } \\
\text { Deviasi } \\
\text { Empinis }\end{array}$ & $\begin{array}{l}\text { Sebaran } \\
\text { Teoretis }\end{array}$ & $\begin{array}{l}\text { Sebaran } \\
\text { Empiris }\end{array}$ \\
\hline Sikap & 115 & 107,5 & 99,08 & 21,5 & 27,771 & $43-172$ & $46-172$ \\
\hline Intimacy & 115 & 75 & 96,47 & 20 & 21,267 & $15-135$ & $39-135$ \\
\hline Passion & 115 & 75 & 84,13 & 20 & 25,059 & $15-135$ & $19-135$ \\
\hline Commitment & 115 & 75 & 101,25 & 20 & 24,333 & $15-135$ & $30-135$ \\
\hline
\end{tabular}

Pada tabel 1, dapat dilihat bahwa sikap terhadap hubungan seksual pranikah memiliki mean empiris yang lebih kecil dari mean teoretis. Hal tersebut menunjukkan bahwa subjek memiliki taraf sikap terhadap hubungan seksual pranikah yang negatif, dalam artian sikap yang tidak mendukung atau menolak terhadap hubungan seksual pranikah. Rentang skor subjek penelitian berkisar dari 44 sampai dengan 172. Berdasarkan penyebaran frekuensi, $33,9 \%$ subjek pada penelitian ini berada di atas mean teoretis.

Pada tabel 1, dapat dilihat bahwa komponen intimacy memiliki mean empiris yang lebih besar dari mean teoretis. Hal tersebut menunjukkan bahwa subjek memiliki taraf intimacy yang tinggi. Rentang skor subjek penelitian berkisar dari 39 sampai dengan 135. Berdasarkan penyebaran frekuensi, $80,9 \%$ subjek pada penelitian ini berada di atas mean teoretis.

Pada tabel 1, dapat dilihat bahwa komponen passion memiliki mean empiris yang lebih besar dari mean teoretis. Hal tersebut menunjukkan bahwa subjek memiliki taraf passion yang tinggi. Rentang skor subjek penelitian berkisar dari 19 sampai dengan 135. Berdasarkan penyebaran frekuensi, $60,9 \%$ subjek pada penelitian ini berada di atas mean teoretis. 
Pada tabel 1, dapat dilihat bahwa komponen commitment memiliki mean empiris yang lebih besar dari mean teoretis. Hal tersebut menunjukkan bahwa subjek memiliki taraf commitment yang tinggi. Rentang skor subjek penelitian berkisar dari 30 sampai dengan 135. Berdasarkan penyebaran frekuensi, $83,5 \%$ subjek pada penelitian ini berada di atas mean teoretis.

\section{Uji asumsi}

Uji asumsi terdiri dari uji normalitas, uji linearitas dan uji multikolinearitas. Uji normalitas dilakukan untuk mengetahui normal atau tidaknya sebaran skor variabel bebas dan variabel tergantung (Sugiyono, 2014). Apabila nilai probabilitas lebih besar dari 0,05, maka distribusi data dalam penelitian ini bersifat normal (Santoso, 2005). Uji normalitas pada penelitian ini menggunakan uji Kolmogorov-Smirnov. Hasil uji normalitas dapat dilihat pada tabel 2. Pada tabel 2, dapat diketahui bahwa data variabel sikap terhadap hubungan seksual pranikah berdistribusi normal dengan nilai kolmogorov-smirnov sebesar 0,657 dan nilai signifikansi sebesar 0,782 ( $\mathrm{p}>0,05)$. Data komponen intimacy berdistribusi normal dengan nilai kolmogorov-smirnov sebesar 0,426 dan nilai signifikansi sebesar 0,993 ( $\mathrm{p}>0,05)$. Data komponen passion berdistribusi normal dengannilai kolmogorov-smirnov sebesar 0,599 dan nilai signifikansi sebesar 0,866 ( $\mathrm{p}>0,05)$. Data komponen commitment berdistribusi normal dengan nilai kolmogorov-smirnov sebesar 0,887 dan nilai signifikansi sebesar 0,411 ( $p>0,05)$.

Tabel 2.

Hasil Uji Normalitas Data Penelitian

\begin{tabular}{ccc}
\hline Variabel & Kolmogorov-Smirnov & Asymp. Sig. (2-tailed) \\
\hline Sikap terhadap hubungan & 0,657 & 0,782 \\
seksual pranikah & 0,426 & 0,993 \\
Intimacy & 0,599 & 0,866 \\
Passion & 0,887 & 0,411 \\
Commitment &
\end{tabular}

Uji linearitas dilakukan dengan tujuan untuk mengetahui apakah secara signifikan dua variabel atau lebih mempunyai hubungan yang linear atau tidak (Sugiyono, 2012). Uji linearitas pada penelitian ini menggunakan teknik comparemeans dengan melihat nilai testoflinearity. Hubungan antara variabel bebas dengan variabel tergantung dikatakan linear apabila nilai signifikansi pada linearitykurang dari 0,05 $(\mathrm{p}<0,05)$ (Priyatno, 2012). Hasil uji linearitas dapat dilihat pada tabel 3. Pada tabel 3, dapat diketahui bahwa hubungan antara sikap dengan intimacy menghasilkan nilai signifikansi pada Linearity sebesar 0,030 $\quad(\mathrm{p}<0,05)$. Hal tersebut menunjukkan adanya hubungan yang linear antara sikap dengan intimacy. Pada hubungan antara sikap dengan passion menghasilkan nilai signifikansi pada Linearity sebesar 0,000 $(\mathrm{p}<0,05)$. Hal tersebut menunjukkan adanya hubungan yang linear antara sikap dengan passion. Pada hubungan antara sikap dengan commitment menghasilkan nilai signifikansi pada Linearity sebesar 0,010 $(\mathrm{p}<0,05)$. Hal tersebut menunjukkan adanya hubungan yang linear antara sikap dengan commitment.

\begin{tabular}{|c|c|c|c|c|}
\hline & & & $\mathrm{F}$ & Sig. \\
\hline \multirow[t]{2}{*}{ Sikap*Intimacy } & \multirow{2}{*}{$\begin{array}{c}\text { Between } \\
\text { Groups }\end{array}$} & (Combined) & 1,022 & 0,468 \\
\hline & & $\begin{array}{c}\text { Linearity } \\
\text { Deviation from Linearity }\end{array}$ & $\begin{array}{l}4,986 \\
0,952\end{array}$ & $\begin{array}{l}0,030 \\
0,573\end{array}$ \\
\hline \multirow[t]{2}{*}{ Sikap*Passion } & \multirow{2}{*}{$\begin{array}{c}\text { Between } \\
\text { Groups }\end{array}$} & (Combined) & 1,968 & 0,007 \\
\hline & & $\begin{array}{c}\text { Linearity } \\
\text { Deviation from Linearity }\end{array}$ & $\begin{array}{c}53,682 \\
1,134\end{array}$ & $\begin{array}{l}0,000 \\
0,324\end{array}$ \\
\hline \multirow[t]{2}{*}{ Sikap*Commitment } & \multirow{2}{*}{$\begin{array}{c}\text { Between } \\
\text { Groups }\end{array}$} & (Combined) & 1,412 & 0,099 \\
\hline & & $\begin{array}{c}\text { Linearity } \\
\text { Deviation from Linearity }\end{array}$ & $\begin{array}{l}7,203 \\
1,310 \\
\end{array}$ & $\begin{array}{l}0,010 \\
0,157\end{array}$ \\
\hline
\end{tabular}

Uji multikolinearitas adalah uji untuk melihat apakah variabel bebas memiliki hubungan atau tidak (Santoso, 2005). Keadaan multikolinearitas dapat dilihat dari nilai Variance Inflation Factor (VIF) dan Tolerance.Jika nilai VIF dibawah 10 dan nilai Tolerance di atas 0,1 maka dinyatakan tidak terjadi multikolinearitas (Yudiaatmaja, 2013). Hasil uji multikolinearitas dapat dilihat pada tabel 4. Pada tabel 4, dapat diketahui bahwa pada komponen intimacy menghasilkan nilai VIF sebesar 2,220 dan nilai Tolerance sebesar 0,450. Berdasarkan nilai tersebut, maka dapat disimpulkan bahwa tidak terjadi multikolinearitas. Pada komponen passion menghasilkan nilai VIF sebesar 2,049 dan nilai Tolerance sebesar 0,488. Berdasarkan nilai tersebut, maka dapat disimpulkan bahwa tidak terjadi multikolinearitas. Pada komponen commitment menghasilkan nilai VIF sebesar 2,515 dan nilai Tolerance sebesar 0,398. Berdasarkan nilai tersebut, maka dapat disimpulkan bahwa tidak terjadi multikolinearitas.

\begin{tabular}{|c|c|c|c|c|}
\hline \multirow{2}{*}{ Komponen } & \multirow{2}{*}{ Signifikansi } & \multicolumn{2}{|c|}{ Collinearity Statistics } & \multirow[b]{2}{*}{ Keterangan } \\
\hline & & Tolerance & VIF & \\
\hline Intimacy & 0,227 & 0,450 & 2,220 & $\begin{array}{c}\text { Tidak ada } \\
\text { multikolinearitas }\end{array}$ \\
\hline Passion & 0,000 & 0,488 & 2,049 & $\begin{array}{c}\text { Tidak ada } \\
\text { multikolinearitas }\end{array}$ \\
\hline Commitment & 0,080 & 0,398 & 2,515 & $\begin{array}{c}\text { Tidak ada } \\
\text { multikolinearitas }\end{array}$ \\
\hline
\end{tabular}

Berdasarkan hasil uji asumsi pada data penelitian yang telah dilakukan, menghasilkan kesimpulan bahwa data penelitian memiliki distribusi yang normal, memiliki hubungan yang linear dan tidak terjadi multikolinearitas diantara komponen pada variabel bebas.

\section{Uji hipotesis}

Uji hipotesis dalam penelitian ini dilakukan dengan menggunakan metode analisis regresi berganda untuk pembuktian hipotesis mayor dan hipotesis minor. Hasil uji regresi berganda komponen intimacy, passion dan commitment dengan variabel sikap terhadap hubungan seksual pranikah dapat dilihat pada tabel 5,6,7 berikut ini: 
Tabel 5 .

Hasil Uji Regresi Berganda Intimacy, Passion dan Commitment dengan Sikap terhadap Hubungan Seksual Pranikah

\begin{tabular}{cccc}
\hline $\mathrm{R}$ & R Square & Adjusted R Square & Std. Error of the Estimate \\
\hline 0,599 & 0,359 & 0,341 & 22,539 \\
\hline
\end{tabular}

Hasil uji regresi berganda pada tabel 5, menunjukkan bahwa hubungan yang terjadi antara variabel bebas dan variabel tergantung dilihat dari nilai koefisien regresi $(\mathrm{R})$ yang dihasilkan adalah sebesar 0,599. Koefisien determinasi ( $\mathrm{R}$ Square) menghasilkan nilai 0,359 yang berarti sumbangan efektif dari komponen intimacy, passion dan commitment secara bersama-sama dengan sikap terhadap hubungan seksual pranikah adalah sebesar 35,9\%, sedangkan sisanya sebesar $64,1 \%$ dipengaruhi oleh variabel atau faktor-faktor lain yang tidak diteliti dalam penelitian ini.

\begin{tabular}{|c|c|c|c|c|c|}
\hline Model & $\begin{array}{l}\text { Sum of } \\
\text { Squares }\end{array}$ & $\mathrm{Df}$ & Mean Square & $\mathrm{F}$ & Sig. \\
\hline Regression & 31531,160 & 3 & 10510,387 & 20,689 & 0,000 \\
\hline Residual & 56389,135 & 111 & 508,010 & & \\
\hline Total & 87920,296 & 114 & & & \\
\hline
\end{tabular}

Hasil uji regresi berganda pada tabel 6, menghasilkan nilai $\mathrm{F}$ hitung sebesar 20,689 dengan tingkat signifikansi sebesar $0,000(\mathrm{p}<0,05)$. Nilai probabilitas yang dihasilkan lebih kecil dari 0,05, maka hal ini berarti model regresi dapat digunakan untuk memprediksi sikap terhadap hubungan seksual pranikah atau dengan kata lain intimacy, passion dan commitment secara bersama-sama berperan pada sikap terhadap hubungan seksual pranikah.

\begin{tabular}{|c|c|c|c|c|c|}
\hline \multirow[t]{2}{*}{ Model } & \multicolumn{2}{|c|}{$\begin{array}{l}\text { Unstandardized } \\
\text { Coefficients }\end{array}$} & \multirow{2}{*}{$\begin{array}{c}\text { Standardized } \\
\text { Coefficients }\end{array}$} & \multirow[b]{2}{*}{$\mathrm{t}$} & \multirow[b]{2}{*}{ Sig. } \\
\hline & B & Std. Error & & & \\
\hline (Constant) & 67,641 & 10,188 & & 6,639 & 0,000 \\
\hline Intimacy & $-0,180$ & 0,148 & $-0,138$ & $-1,215$ & 0,227 \\
\hline Passion & 0,872 & 0,121 & 0,787 & 7,234 & 0,000 \\
\hline Commitment & $-0,243$ & 0,138 & $-0,213$ & $-1,765$ & 0,080 \\
\hline
\end{tabular}

Hasil uji regresi berganda pada tabel 7, menunjukkan nilai dari koefisien beta terstandarisasi pada komponen passion bernilai lebih besar dibandingkan nilai koefisien beta terstandarisasi pada komponen intimacy dan commitment. Hal ini menunjukkan bahwa komponen passion memiliki peran lebih banyak pada sikap terhadap hubungan seksual pranikah dibandingkan komponen intimacy dan commitment. Komponen intimacy memiliki koefisien beta terstandarisasi sebesar -0,138 dengan nilai $\mathrm{t}$ sebesar -1,215 dan taraf signifikansi $0,227(\mathrm{p}>0,05)$. Hal ini berarti intimacy tidak berperan secara signifikan pada sikap terhadap hubungan seksual pranikah karena nilai signifikansi yang dihasilkan lebih besar dari 0,05. Komponen passion memiliki koefisien beta terstandarisasi sebesar 0,787 dengan nilai t sebesar 7,234 dan taraf signifikansi $0,000(\mathrm{p}<0,05)$. Hal ini berarti passion berperan secara signifikan pada sikap terhadap hubungan seksual pranikah. Komponen commitment memiliki koefisien beta terstandarisasi sebesar -0,213 dengan nilai $\mathrm{t}$ sebesar 1,765 dan taraf signifikansi 0,080 ( $p>0,05)$. Hal ini berarti commitment tidak berperan secara signifikan pada sikap terhadap hubungan seksual pranikah karena nilai signifikansi yang dihasilkan lebih besar dari 0,05 .

Rangkuman hasil uji hipotesis mayor dan hipotesis minor dalam penelitian ini dapat dilihat pada tabel 8 . Tabel 8.

\begin{tabular}{|c|c|c|}
\hline No. & Hipotesis & Hasil \\
\hline 1. & $\begin{array}{l}\text { Hipotesis Mayor } \\
\text { Komponen cinta berperan pada sikapterhadap hubungan seksual } \\
\text { pranikah remaja akhir yang berpacaran di Kabupaten Bangli }\end{array}$ & Diterima \\
\hline \multirow[t]{3}{*}{2.} & $\begin{array}{l}\text { Hipotesis Minor } \\
\text { a. Intimacy berperan pada sikap terhadap hubungan seksual } \\
\text { pranikah remaja akhir yang berpacaran di Kabupaten Bangli }\end{array}$ & Ditolak \\
\hline & $\begin{array}{l}\text { b. Passion berperan pada sikap terhadap hubungan seksual } \\
\text { pranikah remaja akhir yang berpacaran di Kabupaten Bangli }\end{array}$ & Diterima \\
\hline & $\begin{array}{l}\text { c. Commitment berperan pada sikap terhadap hubungan seksual } \\
\text { pranikah remaja akhir yang berpacaran di Kabupaten Bangli }\end{array}$ & Ditolak \\
\hline
\end{tabular}

\section{Analisis tambahan}

Analisis tambahan dalam penelitian ini berupa uji beda pada data demografi jenis kelamin terhadap variabel tergantung yaitu sikap terhadap hubungan seksual pranikah. Uji beda data tambahan dilakukan untuk mengetahui perbedaan sikap terhadap hubungan seksual pranikah berdasarkan jenis kelamin subjek. Uji beda dalam penelitian ini dilakukan dengan menggunakan independent sample t test. Hasil uji beda variabel sikap terhadap hubungan seksual pranikah berdasarkan jenis kelamin dapat dilihat pada tabel 9 dan 10 .

\begin{tabular}{|c|c|c|c|c|c|}
\hline \multirow{3}{*}{$\begin{array}{c}\text { Sikap } \\
\text { Terhadap } \\
\text { Hubungan } \\
\text { Seksual } \\
\text { Pranikah }\end{array}$} & \multirow[b]{2}{*}{$\begin{array}{c}\text { Equal } \\
\text { variances } \\
\text { assumed }\end{array}$} & \multicolumn{2}{|c|}{$\begin{array}{c}\text { Levene's Test for Equality of } \\
\text { Variances }\end{array}$} & \multicolumn{2}{|c|}{ t-test for Equality of Means } \\
\hline & & \multirow{2}{*}{$\underset{3,859}{F}$} & \multirow{2}{*}{$\begin{array}{c}\text { Sig. } \\
0,052\end{array}$} & $\begin{array}{c}\mathrm{T} \\
8,078\end{array}$ & $\begin{array}{l}\text { Sig. }(2 \text {-tailed }) \\
0,000\end{array}$ \\
\hline & $\begin{array}{c}\text { Equal } \\
\text { variances not } \\
\text { assumed }\end{array}$ & & & 7,994 & 0,000 \\
\hline
\end{tabular}

Berdasarkan pada tabel 9, analisis dilakukan dengan pertamatama melihat nilai pada levene's test for equality of variances. Jika nilai signifikansi lebih kecil dari 0,05 ( $<<0,05)$, maka varians pada subjek laki-laki dan perempuan tidak identik atau berbeda. Jika nilai signifikansi lebih besar dari 0,05 ( $p>0,05)$, maka varians pada subjek laki-laki dan perempuan identik atau sama. Pada tabel 9, dapat diketahui bahwa nilai $\mathrm{F}$ hitung pada kolom levene's test for equality of variances sebesar 3,859 dengan signifikansi sebesar 0,052 ( $>>0,05)$, artinya kedua varians identik atau sama. Diasumsi bahwa kedua varians identik atau sama, maka penggunaan varians untuk membandingkan rata-rata populasi dengan t test sebaiknya menggunakan dasar equal variance not assummed (Santoso, 2005). Nilai t hitung pada baris equal variance not assummed 
adalah sebesar 7,994 dengan signifikansi 0,000 ( $\mathrm{p}<0,05)$. Artinya rata-rata sikap terhadap hubungan seksual pranikah laki-laki dan perempuan memiliki perbedaan atau terdapat perbedaan sikap terhadap hubungan seksual pranikah berdasarkan jenis kelamin.

$\begin{aligned} & \text { Tabel } 10 . \\
& \text { Ringkasan Statistik Uji Tambahan Variabel Sikap terhadap Hubungan Seksual Pranikah } \\
& \text { Berdasarkan Jenis Kelamin }\end{aligned}$
\begin{tabular}{ccccc}
\hline Jenis Kelamin & N & Mean & Std. Deviation & $\begin{array}{c}\text { Std. Error } \\
\text { Mean }\end{array}$ \\
\hline Laki-laki & 56 & 116,25 & 26,385 & 3,526 \\
Perempuan & 59 & 82,78 & 17,343 & 2,258 \\
\hline
\end{tabular}

Berdasarkan pada tabel 10, dengan melihat nilai pada kolom mean dapat diketahui bahwa nilai rata-rata sikap terhadap hubungan seksual pranikah pada laki-laki lebih tinggi daripada perempuan. Nilai rata-rata pada laki-laki adalah sebesar 116,25 dan nilai rata-rata pada perempuan sebesar 82,78. Artinya bahwa laki-laki memiliki sikap yang lebih positif terhadap hubungan seksual pranikah dibandingkan dengan perempuan.

\section{PEMBAHASAN DAN KESIMPULAN}

Berdasarkan hasil penelitian yang telah dipaparkan, dapat disimpulkan bahwa hipotesis mayor dalam penelitian ini yaitu komponencinta berperan pada sikap terhadap hubungan seksual pranikah remaja akhir yang berpacaran di Kabupaten Bangli dapat diterima. Hal ini berdasarkan pada hasil analisis regresi berganda yang telah dilakukan, menunjukkan bahwa komponen intimacy, passion dan commitment secara bersamasama berperan pada sikap terhadap hubungan seksual pranikah. Sternberg (1986) menjelaskan bahwa dalam suatu hubungan berpacaran terdapat tiga komponen utama cinta yang terdiri dari komponen intimacy, passion dan commitment. Sternberg (1988) menyatakan bahwa hubungan yang hanya memiliki satu komponen lebih sulit untuk dipertahankan dibandingkan dengan hubungan yang memiliki dua komponen atau ketiga komponen cinta didalamnya. Adanya ketiga komponen cinta yakni intimacy, passion, dan commitment yang dimiliki individu dalam suatu hubungan sangat menentukan atau memengaruhi terbentuknya cinta, sehingga ketika ketiga komponen tersebut hadir secara bersama-sama dalam sebuah hubungan maka akan menghasilkan cinta yang ideal. Komponen cinta dapat membentuk sikap positif individu terhadap hubungan seksual pranikah karena dengan hadirnya ketiga komponen cinta secara bersama-sama dalam sebuah hubungan, maka individu akan berusaha memenuhi keinginan untuk mengaktualisasikan rasa cinta kepada pasangannya yang dapat ditunjukkan dengan kesediaan untuk melakukan hubungan seksual bersama pasangan (Setyawan, 2004). Hal tersebut dapat membentuk sikap positif yang berarti individu setuju terhadap hubungan seksual yang dilakukan sebelum menikah.
Koefisien determinasi pada penelitian ini menghasilkan nilai sebesar 0,359 yang berarti bahwa komponen intimacy, passion dan commitment secara bersamasama memiliki sumbangan efektif sebesar $35,9 \%$ pada sikap terhadap hubungan seksual pranikah. Hal ini menunjukkan bahwa 35,9\% variasi dalam sikap terhadap hubungan seksual pranikah pada remaja akhir yang berpacaran di Kabupaten Bangli ditentukan oleh taraf intimacy, passion dan commitment, sedangkan $64,1 \%$ ditentukan oleh faktor atau variabel lain yang tidak diteliti dalam penelitian ini. Penelitian yang dilakukan oleh Widyastuti (2009) menunjukkan bahwa faktor personal dan sosial yang dapat memengaruhi sikap remaja terhadap hubungan seksual pranikah diantaranya adalah jenis kelamin, sikap seksualitas teman dekat dan paparan seksual. Lain halnya dengan penelitian yang dilakukan oleh Setyorini (2014) yang menghasilkan bahwa konformitas teman sebaya dan intensitas akses pornografi di internet memiliki pengaruh terhadap sikap mengenai hubungan seksual pranikah remaja. Faktor-faktor ini dapat menjadi referensi bagi peneliti selanjutnya yang ingin meneliti mengenai sikap terhadap hubungan seksual pranikah.

Hasil koefisien beta terstandarisasi menunjukkan bahwa dari ketiga komponen cinta yaitu intimacy, passion dan commitment, hanya komponen passion yang secara parsial berperan signifikan dalam pembentukan sikap terhadap hubungan seksual pranikah remaja akhir yang berpacaran. Komponen intimacy dan commitment tidak berperan secara signifikan pada sikap terhadap hubungan seksual pranikah. Dalam hal ini, komponen passion lebih berperan mendorong individu untuk melakukan hubungan seksual dengan pasangannya karena passion didasari atas ekspresi dari berbagai keinginan dan kebutuhan yang salah satunya adalah pemenuhan kebutuhan seksual (Sternberg, 1986). Hasil penelitian oleh Guntari (2011) menunjukkan bahwa passion tidak berkontribusi secara signifikan pada sikap terhadap hubungan seksual pranikah. Hasil penelitian tersebut bertolak belakang dengan temuan dalam penelitian ini yang menunjukkan bahwa komponen passion secara parsial berperan signifikan pada sikap terhadap hubungan seksual pranikah.

Teori Sternberg (1998) menyatakan bahwa passion merupakan komponen yang paling berperan dalam memotivasi pembentukan hubungan romantis, yang secara dominan termanifestasi dalam bentuk ketertarikan fisik dan pemenuhan kebutuhan seksual dengan pasangan. Dalam hubungan cinta romantis, ketertarikan fisik dan seksual mungkin adalah hal yang utama, namun motif yang lainnya seperti kebutuhan akan harga diri, kebutuhan akan afiliasi dan kebutuhan untuk mendominasi juga berkontribusi dalam passion (Sternberg, 1986). Passion merupakan unsur motivasional yang menyebabkan individu merasa ingin dekat secara fisik, menikmati atau merasakan sentuhan fisik, bahkan 
melakukan hubungan seksual dengan pasangannya (Sternberg, 2006). Komponen passion memiliki pengaruh kuat pada pasangan yang sedang berpacaran untuk melakukan hubungan seksual. Jika pasangan tidak dapat mengontrol passion yang ada di dalam diri mereka, maka perilaku yang akan muncul seperti bergandengan tangan, berpelukan, berciuman, atau bahkan sampai berhubungan seksual (Sternberg, 1998). Hasil penelitian ini sejalan dengan teori yang dikemukakan oleh Sternberg (1998), bahwa passion merupakan komponen yang paling berperan dalam memunculkan perilaku yang mengarah kepada hubungan seksual pranikah. Hadirnya passion dalam sebuah hubungan cinta dapat memunculkan ketertarikan fisik dan dorongan seksual terhadap pasangan (Lehmiller, 2014), dengan demikian passion dapat membentuk sikap yang positif pada individu terhadap hubungan seksual pranikah. Hal tersebut dikarenakan individu memiliki hasrat seksual yang membutuhkan penyaluran dalam bentuk tingkah laku seksual tertentu (Sarwono, 2013), sehingga pasangan dengan passion dalam sebuah hubungan akan bersedia atau setuju untuk melakukan hubungan seksual pranikah dan hal itu membentuk sikap yang positif pada individu terhadap hubungan seksual pranikah.

Menurut Crooks dan Baur (2004), intimacy merupakan salah satu upaya untuk membantu orang lain, keterbukaan, saling berbagi dan bertukar pikiran, serta merasakan suka maupun duka bersama orang yang dicintai. Berdasarkan hasil uji regresi koefisien beta terstandarisasi dan nilai t menunjukkan bahwa komponen intimacy tidak berperan secara signifikan pada sikap terhadap hubungan seksual pranikah remaja akhir. Individu dengan intimacy akan memiliki rasa kedekatan dengan seseorang, berkomunikasi secara intim, senang berbincang-bincang dengan pasangan dalam waktu yang lama dan merasa rindu bila lama tidak bertemu (Sternberg, 1988). Individu akan menikmati berada di dekat pasangannya untuk melakukan hal-hal yang menyenangkan secara bersama-sama. Individu yang hanya memiliki komponen intimacy dalam sebuah hubungan digolongkan ke dalam tipe cinta liking (Sternberg, 1998). Individu akan merasa dekat, saling terikat dan nyaman terhadap pasangan tanpa adanya gairah maupun komitmen. Tipe cinta ini seperti hubungan persahabatan yang dekat (close friendship) (Sternberg, 1998).

Ketika dalam sebuah hubungan, komponen intimacy yang lebih menonjol atau dominan, maka dapat dikatakan bahwa hubungan tersebut terasa seperti hubungan dengan sahabat. Secara emosional ada ikatan dengan individu tersebut, tetapi tidak ada gairah yang muncul atau keinginan untuk menghabiskan hidup bersama dengan individu tersebut (Sternberg, 1988). Dengan demikian, intimacy tidak dapat memunculkan dorongan yang berkaitan dengan pemenuhan kebutuhan seksual dalam hubungan berpacaran seperti hubungan seksual pranikah karena intimacy menyangkut masalah emosional yang melibatkan pengungkapan diri (self disclosure) dan akan menghasilkan suatu keterkaitan, kehangatan, kepercayaan, dan keinginan untuk membina hubungan (Papalia, 2004). Individu belum bersedia untuk melakukan hubungan seksual dengan pasangannya karena individu menganggap hubungan cinta seperti seorang sahabat yang penuh kedekatan dan kehangatan sudah cukup baik dan membuat nyaman. Jadi intimacy belum sampai membentuk sikap yang positif terhadap hubungan seksual pranikah karena individu akan membuktikan cinta mereka dengan cara yang sehat dan sewajarnya tanpa adanya pikiran untuk melakukan hubungan seksual dengan pasangan.

Commitment mengacu pada kekuatan yang berkaitan dengan keinginan seseorang untuk melanjutkan hubungan (Brehm, 1992). Berdasarkan hasil uji regresi koefisien beta terstandarisasi dan nilai $\mathrm{t}$ menunjukkan bahwa komponen commitment tidak berperan secara signifikan pada sikap terhadap hubungan seksual pranikah remaja akhir pada penelitian ini. Commitment terdiri dari dua aspek, yang bersifat jangka pendek dan yang bersifat jangka panjang. Untuk aspek jangka pendek, komponen commitment merupakan keputusan untuk mencintai seseorang, sedangkan untuk aspek jangka panjang, komponen commitment merupakan komitmen untuk mempertahankan cinta itu (Sternberg, 2006). Kedua aspek tersebut tidak harus terjadi secara bersama-sama.Individu dengan commitment akan memiliki rasa kepercayaan terhadap pasangan mengenai kemungkinan hubungan mereka untuk berlanjut, prediksi mengenai masa depan dari hubungan dan konsepsi akan stabilitasnya (Surra \& Hughes, 1997). Commitment merupakan dorongan kognitif yang mendorong individu tetap mempertahankan hubungan cinta dengan pasangan yang dicintainya (Sternberg, 1988). Adanya rintangan, godaan, atau hambatan dalam sebuah hubungan akan menjadi pemicu bagi masing-masing individu untuk membuktikan ketulusan cinta terhadap pasangannya.

Commitment akan terlihat dengan adanya upayaupaya tindakan cinta yang cenderung meningkatkan rasa percaya, rasa diterima, merasa berharga, dan merasa dicintai oleh pasangan (Sternberg, 1998). Individu yang hanya memiliki komponen commitment dalam sebuah hubungan digolongkan ke dalam tipe cinta empty love. Tipe cinta ini hanya memiliki elemen komitmen tanpa gairah dan keintiman (Sternberg, 2006). Empty love biasanya ditemukan pada hubungan yang telah berlangsung selama bertahun-tahun dan masing-masing pasangan telah kehilangan keterlibatan emosional serta ketertarikan fisik (Sternberg, 1988). Tanpa adanya rasa kedekatan emosional, keintiman, hasrat atau gairah, maka individu tidak memiliki dorongan seksual terhadap pasangannya. Individu tidak akan berpikir untuk melakukan hubungan seksual pranikah dengan pasangannya karena individu hanya berkomitmen untuk tetap setia dan 
mempertahankan hubungannya tanpa adanya keinginan untuk menjalin hubungan seksual. Dengan demikian, commitment belum sampai membentuk sikap yang positif terhadap hubungan seksual pranikah karena individu hanya berfokus untuk mempertahankan hubungannya.

Berdasarkan hasil kategorisasi, dapat diketahui bahwa remaja akhir yang berpacaran di Kabupaten Bangli memiliki sikap yang cenderung tidak terlalu ke arah negatif ataupun positif terhadap hubungan seksual pranikah. Hal ini sejalan dengan data deskriptif pada variabel bebas terutama komponen passion yang tergolong sedang, karena hanya komponen passion yang berperan secara parsial pada sikap terhadap hubungan seksual pranikah. Krech, Crutchfield dan Ballachev (1982) menyatakan bahwa terbentuknya sikap salah satunya dipengaruhi oleh faktor lingkungan yang anggotanya adalah individu itu sendiri. Individu cenderung menyesuaikan sikapnya dengan sikap pada kelompok karena individu menginginkan dirinya diterima oleh kelompoknya (social desirability). Individu cenderung menjawab sesuai dengan norma yang berlaku di masyarakat dan memungkinkan adanya faking pada jawaban yang diberikan sehingga menghasilkan taraf sikap yang tidak terlalu ke arah negatif ataupun positif terhadap hubungan seksual pranikah. Hal ini menjadi perhatian bagi peneliti selanjutnya untuk lebih memperhatikan indeks social desirability dalam penelitian.

Berdasarkan hasil kategorisasi, dapat diketahui bahwa remaja akhir yang berpacaran di Kabupaten Bangli memiliki taraf intimacy yang tergolong tinggi. Pasangan yang sangat memperhatikan kesejahteraan dan kebahagiaan pasangannya, menghormati dan menghargai satu sama lain, dan memiliki rasa saling pengertian akan merasakan kedekatan dan kehangatan dalam hubungannya bersama pasangan sehingga individu akan memiliki taraf intimacy yang tinggi (Sternberg, 1988).

Berdasarkan hasil kategorisasi, dapat diketahui bahwa remaja akhir yang berpacaran di Kabupaten Bangli memiliki taraf passion yang tergolong sedang. Dalam perkembangan seksualitas remaja, faktor yang berhubungan dengan seksualitas remaja adalah faktor biologis dan faktor psikologis. Faktor biologis berkaitan dengan perkembangan pada masa pubertas dan waktu mulai pubertas yang keduanya berkaitan dalam meningkatkan ketertarikan seksual serta kemungkinan yang lebih besar dari awal untuk terlibat dalam hubungan seksual. Faktor psikologis meliputi sikap, tujuan akademik, kecenderungan pengambilan risiko, penyesuaian psikologis, dan karakteristik dari keluarga (Hill, 2008). Adanya ketertarikan seksual pada faktor biologis dan sikap pada faktor psikologis merupakan faktor yang berhubungan dengan seksualitas remaja. Ketertarikan seksual merupakan elemen dalam passion (Sternberg, 1998), sehingga adanya ketertarikan seksual pada remaja dapat memunculkan aktivitas yang berkaitan dengan hubungan seksual pranikah. Taraf passion yang tergolong sedang dikarenakan rata-rata subjek mampu mengontrol ketertarikan seksual pada pasangan serta mengontrol hasrat atau gairah yang ada didalam dirinya selama berpacaran. Adanya batasan-batasan perilaku pada remaja ketika berpacaran, nilai-nilai moral yang dianut serta norma agama yang berlaku di masyarakat dapat mengontrol gairah seksual dalam diri individu (Sarwono, 2013).

Berdasarkan hasil kategorisasi, dapat diketahui bahwa remaja akhir yang berpacaran di Kabupaten Bangli memiliki taraf commitment yang tergolong sangat tinggi. Adanya commitment terhadap hubungan dapat membuat seseorang merasa lebih puas dengan hubungannya. Apabila ekspresi dari commitment disadari dan diapresiasi oleh pasangan, maka hal ini dapat membawa dampak positif terhadap kepercayaan terhadap pasangan (Zakiah, 2012). Individu yang telah merasa nyaman dengan hubungannya, merasa sangat cocok dengan pasangan, serta memutuskan untuk saling setia akan memiliki harapan dapat menghabiskan hidup bersama dan berharap hubungan dengan pasangannya dapat berlanjut hingga di masa depan (Sternberg, 1998), maka hal tersebut menyebabkan individu memiliki taraf commitment yang sangat tinggi dalam hubungannya.

Hasil analisis tambahan menggunakan uji independent sample $\mathrm{t}$ test pada variabel sikap terhadap hubungan seksual pranikah berdasarkan jenis kelamin menunjukkan bahwa terdapat perbedaan sikap antara laki-laki dengan perempuan terhadap hubungan seksual pranikah. Dilihat dari nilai rata-rata sikap terhadap hubungan seksual pranikah antara laki-laki dan perempuan menghasilkan bahwa nilai rata-rata pada laki-laki lebih tinggi dibandingkan perempuan. Hal tersebut menunjukkan bahwa laki-laki memiliki sikap yang lebih positif terhadap hubungan seksual pranikah daripada perempuan. Hal ini sejalan dengan penelitian yang dilakukan oleh Ramanaidoo dan Rathakrishnan (2012) yang menemukan bahwa terdapat perbedaan sikap antara laki-laki dan perempuan mengenai hubungan seksual sebelum menikah yaitu laki-laki bersikap lebih terbuka terhadap hubungan seksual sebelum menikah dibandingkan dengan perempuan. Hasil penelitian oleh Widyastuti (2009) juga menemukan adanya perbedaan sikap terhadap hubungan seksual pranikah antara laki-laki dan perempuan yaitu laki-laki mempunyai kecenderungan yang lebih besar untuk bersikap permisif daripada perempuan. Shaluhiyah (2006) menyebutkan bahwa adanya pola hubungan yang tidak seimbang antara laki-laki dan perempuan serta dominannya norma maskulinitas pada norma seksualitas memunculkan adanya standar ganda yang lebih menerima hubungan seksual pranikah yang dilakukan laki-laki daripada perempuan. Sarwono (2013) menyatakan bahwa salah satu faktor yang memengaruhi hubungan seksual adalah perbedaan jenis kelamin antara laki-laki dan perempuan. Adanya normanorma yang lebih longgar bagi laki-laki dibandingkan 
perempuan sehingga lebih besar kemungkinan laki-laki untuk melakukan hal-hal yang berkaitan dengan masalah seksual daripada perempuan.

Keterbatasan dalam penelitian ini adalah saat pengambilan data penelitian, kurangnya pengawasan dan kontrol yang baik menyebabkan terdapat beberapa subjek yang tidak mengisi skala kedua sehingga skala tersebut tidak dapat dianalisis.Dengan demikian, setelah melalui prosedur analisis data penelitian, karya tulis ini telah mampu mencapai tujuannya yaitu mengukur peran intimacy, passion dan commitment pada sikap terhadap hubungan seksual pranikah remaja akhir yang berpacaran di Kabupaten Bangli.

Berdasarkan penelitian yang telah dilakukan dan hasil analisis data yang telah dipaparkan, maka dapat ditarik kesimpulan bahwa (a)Intimacy, passion dan commitment secara bersama-sama berperan pada sikap terhadap hubungan seksual pranikah remaja akhir yang berpacaran di Kabupaten Bangli, (b) Intimacy tidak berperan pada sikap terhadap hubungan seksual pranikah remaja akhir yang berpacaran di Kabupaten Bangli,(c) Passion berperan pada sikap terhadap hubungan seksual pranikah remaja akhir yang berpacaran di Kabupaten Bangli. Semakin tinggi passion maka semakin positif sikap terhadap hubungan seksual pranikah.(d) Commitment tidak berperan pada sikap terhadap hubungan seksual pranikah remaja akhir yang berpacaran di Kabupaten Bangli.(e) Sikap terhadap hubungan seksual pranikah pada remaja akhir yang berpacaran di Kabupaten Bangli tergolong tidak terlalu ke arah negatif atau positif dalam artian sikap yang netral.(f) Intimacy remaja akhir yang berpacaran di Kabupaten Bangli tergolong tinggi.(g) Passion remaja akhir yang berpacaran di Kabupaten Bangli tergolong sedang.(h) Commitmentremaja akhir yang berpacaran di Kabupaten Bangli tergolong sangat tinggi.(i) Terdapat perbedaan sikap terhadap hubungan seksual pranikah pada remaja akhir yang berpacaran di Kabupaten Bangli ditinjau dari jenis kelamin. Subjek laki-laki menunjukkan sikap yang lebih positif terhadap hubungan seksual pranikah dibandingkan dengan subjek perempuan.

Berdasarkan kesimpulan tersebut, maka terdapat beberapa saran diantaranya:(a) Bagi remaja yang berpacarandiharapkan dapat menyalurkan perasaan cinta terhadap pasangannya dalam bentuk yang positif dan menerapkan gaya berpacaran yang sehat sehingga remaja yang berpacaran tidak akan terlibat dalam hubungan seksual sebelum menikah. (b) Remaja yang berpacaran hendaknya mempertimbangkan segi baik dan buruk atau dampak positif dan negatif ketika akan mengambil suatu keputusan dari tindakan yang akan dilakukannya. (c) Remaja sebaiknya berpegang teguh pada nilai-nilai yang mereka anut. Dalam artian, antara nilai, prinsip, aturan, norma yang mereka pegang dengan sikap yang ditampilkan sebaiknya sejalan dan tidak bertentangan. Apabila remaja menganggap bahwa hubungan seksual itu tidak boleh dilakukan sebelum menikah karena bertentangan dengan nilai atau prinsip yang dianut, maka sebaiknya remaja tidak melakukan hubungan seksual pranikah bersama pasangannya. Remaja harus berani untuk berkata "tidak", jadi ketika terdapat ajakan untuk melakukan hubungan seksual pranikah maka remaja dapat menolak hal tersebut sehingga remaja tidak melanggar nilai atau prinsip yang yang dipegang.(d) Remaja memiliki sikap terhadap hubungan seksual pranikah yang sudah cukup baik dalam artian sikap yang negatif terhadap hubungan seksual pranikah, maka sebaiknya hal tersebut semakin dipertahankan. Dalam hubungan berpacaran, remaja sebaiknya lebih mengembangkan pola-pola hubungan yang mengandung kedekatan, kehangatan, kebersamaan (intimacy), hubungan persahabatan, serta membangun komitmen dan rasa saling percaya terhadap pasangan.(e) Bagi remaja laki-laki, diharapkan lebih mengedepankan komponen intimacy dan commitment ketika membina sebuah hubungan, jadi tidak hanya menonjolkan komponen passion yang berkaitan dengan hasrat atau gairah.

Saran bagi sekolah/tenaga pendidik/penyuluh yaitu: (a) Penyuluhan-penyuluhan terkait pendidikan seksual kepada remaja sebaiknya tidak hanya menitikberatkan pada komponen passion, misalnya terkait cara berpakaian perempuan yang baik dan sopan agar tidak merangsang lakilaki atau bagaimana cara mengontrol hasrat dan rasa keingintahuan remaja terhadap hal-hal yang berbau seksual. Sebaiknya penyuluhan terkait pendidikan seksual melibatkan ketiga komponen dari cinta yaitu intimacy, passion dan commitment, memikirkan bahwa ketika bersama-sama ketiga komponen tersebut saling berkaitan. Misalnya pentingnya menjalin hubungan persahabatan yang sehat agar terhindar dari pergaulan bebas, pentingnya adanya pengungkapan diri (self disclosure) yaitu berupa pengungkapan informasi penting pada diri individu dengan individu lain sehingga adanya pengungkapan diri tersebut akan menghasilkan suatu keterikatan, kehangatan serta kepercayaan. Pentingnya membangun kepercayaan dan commitment dengan pasangan agar hubungan tidak mengarah ke hal-hal yang bersifat negatif. (b) Penyuluhan terkait pendidikan seksual pada remaja harus dilakukan sebelum usia 18 tahun. Usia remaja awal adalah usia terbaik untuk memberikan pendidikan seksual kepada remaja agar nantinya remaja tidak terjerumus ke dalam perilaku seksual yang salah dan tidak sehat.

Saran bagi peneliti selanjutnya yaitu (a) Peneliti selanjutnya dapat meneliti kembali tentang peran komponen cinta pada sikap terhadap hubungan seksual pranikah. Penelitan-penelitian yang berkaitan masih sangat minim ditemui. Adanya penelitian serupa diharapkan dapat mengurangi terjadinya bias budaya karena penelitian ini dilakukan di negara Indonesia yang memiliki norma-norma agama dan masih menganggap seks sebagai suatu hal yang 
tabu sementara di negara barat pembicaraan terkait seks merupakan hal yang sudah biasa dan bukan hal yang tabu. (b) Peneliti selanjutnya yang ingin meneliti sikap terhadap hubungan seksual pranikah dapat melakukan penelitian dengan menggunakan faktor-faktor yang memengaruhi sikap terhadap hubungan seksual pranikah selain komponen cinta, seperti faktor personal dan sosial yang meliputi jenis kelamin, sikap seksualitas teman dekat dan paparan seksual, serta faktor seperti konformitas teman sebaya dan intensitas akses pornografi di internet, atau faktor lainnya yang digunakan untuk mengetahui seberapa besar hubungan variabel lain tersebut memengaruhi sikap terhadap hubungan seksual pranikah. (c) Peneliti selanjutnya yang ingin meneliti sikap terhadap hubungan seksual pranikah sebaiknya lebih memperhatikan indeks social desirability terutama dalam penyusunan aitem serta lebih dapat mengontrol adanya faking good atau faking bad pada jawaban yang diberikan oleh subjek. (d) Pada saat pengambilan data, peneliti selanjutnya sebaiknya melakukan pengawasan dan kontrol yang lebih baik pada subjek sehingga subjek dapat mengisi skala penelitian dengan sebaik-baiknya dan sejujur-jujurnya.(e) Peneliti selanjutnya dapat meneliti lebih jauh pada remaja laki-laki karena dalam penelitian ini, sikap yang lebih positif terhadap hubungan seksual pranikah lebih tinggi pada remaja laki-laki.

\section{DAFTAR PUSTAKA}

Abisuryo, M. (2016). Hubungan antara intimacy, passion, commitment dan frekuensi mengakses situs porno. Skripsi. Program Studi Psikologi, Fakultas Psikologi, Universitas Sanata Dharma, Yogyakarta.

Arde, L.D. (2011). Hubungan pengetahuan, sikap, dan lingkungan sosial terhadap perilaku seksual remaja di Indonesia tahun 2007 (Analisis data sekunder SKRRI 2007). Skripsi. Fakultas Kesehatan Masyarakat, Universitas Indonesia, Depok.

Atwater, E. (1983). Psychology of adjustment. Second Edition. United States: Prentice-Hall.

Azwar, S. (2007). Sikap manusia: Teori dan pengukurannya. Yogyakarta: Pustaka Pelajar Offset.

Azwar, S. (2013). Reliabilitas dan validitas. Yogyakarta: Pustaka Pelajar.

Azwar, S. (2014). Penyusunan skala psikologi. Second Edition. Yogyakarta: Pustaka Pelajar.

Badan Kependudukan dan Keluarga Berencana Nasional. (2014). Remaja pelaku seks bebas meningkat. Diunduh dari web $\mathrm{BKKBN}$ :

http://www.bkkbn.go.id/ViewBerita.aspx?BeritaID=1761. Diakses pada 18 Maret 2015.

Brehm, S.S. (1992). Intimate relationship. Second Edition. New York: McGraw-Hill, Inc.

Cole, L. (1963). Psychology of adolescence. Fifth Edition. New York: Holt, Rinehart and Winston.

Crooks, R. \& Baur, K. (2004). Our sexuality. Seventh Edition. USA: Brooks/Cole Publishing Company.
Damayanti, R. (2007). Peran biopsikososial terhadap perilaku berisiko tertular HIV pada remaja SLTA di DKI. Disertasi. Fakultas Kesehatan Masyarakat, Universitas Indonesia, Depok.

Desmita, R. (2008). Psikologi perkembangan. Bandung: PT.Remaja Rosdakarya.

Diessner, R., Frost, N. \& Smith, T. (2004). Describing the neoclassical psyche embedded in Sternberg's triangular theory of love: A summary of Sternberg's triangular theory of love. Social Behavior and Personality, 32(7), 683-690.

Duvall, E. \& Miller, C.M. (1985). Marriage and family development. Sixth Edition. New York: Harper \& Row Publisher.

Faisal. (Desember 2015). Angka kehamilan tidak diinginkan di indonesia capai 32 ribu lebih. Diunduh dari http://aceh.tribunnews.com/2015/12/05/angka-kehamilantidak-diinginkan-di indonesia-capai-32-ribu-lebih?page $=2$. Diakses pada 2 Februari 2016.

Faiz, F. (2002). Filosofi cinta Kahlil Gibran. Yogyakarta: Tinta.

Faturochman. (1992). Sikap dan perilaku seksual remaja di Bali. Jurnal Psikologi, 1, 12-17.

Gerungan, W.A. (1966). Psikologi sosial. Bandung: PT. Eresco.

Ghozali, I. (2011). Aplikasi analisis multivariate dengan program IBM SPSS. Semarang: Universitas Diponegoro.

Guntari, P.A. (2011). Kontribusi passion sebagai komponen cinta pada sikap terhadap hubungan seks pranikah mahasiswa Fakultas Psikologi Universitas Gunadarma. Fakultas Psikologi, Universitas Gunadarma, Jakarta.

Hewitt, C. (2006). What is commitment?: Physical, organizational, and social. Faculty of Electrical Engineering And Computer Science, University of Michigan, Michigan.

Hill, C.A. (2008). Human sexuality. Los Angeles: SAGE Publications.

Horison, C. (2014). Hubungan komponen cinta Sternberg dengan kepuasan hubungan romantis pada dunia maya dan dunia nyata. Fakultas Psikologi, Universitas Sumatera Utara, Medan.

Hurlock, E.B. (1980). Psikologi perkembangan: Suatu pendekatan sepanjang rentang kehidupan. Jakarta: Erlangga.

Istikasari, A.R. (2012). Perilaku berpacaran remaja (Studi fenomenologis dimensi hasrat, keintiman, dan komitmen remaja berpacaran). Skripsi. Jurusan Bimbingan dan Konseling, Fakultas Ilmu Pendidikan, Universitas Negeri Malang, Malang.

Karmaya, M. (2014). Seks positif: Sikap positif terhadap seksualitas. Denpasar: Udayana University Press.

Khaldun, R. (2013). Psikologi: Kemampuan kognitif dan sosial emosional pada anak usia remaja akhir. Al-Tazkiah, 1(3), $29-40$.

Kompas.com. (Februari, 2009).Kasus kehamilan tak diinginkan di Bali tinggi. Diunduh dari http://travel.kompas.com/read/2009/02/17/1621399/kasus.k ehamilan.tak.diinginkan.di.bali.tinggi. Diakses pada 2 Februari 2016.

Kompas.com. (September 2009). Astaga sebulan 41 kasus hamil di luar nikah di Bali. Diunduh dari http://regional.kompas.com/read/2009/09/12/21132077/asta ga...sebulan.41.kasus.hamil.di.luar.nikah.di.bali\%20tanggal 
\%2014\%20September\%202009. Diakses pada 30 Januari 2016.

Kontour, R. (2004). Metode penelitian untuk penulisan skripsi dan tesis. Jakarta: Penerbit PPM.

Krech, D., Crutchfield, R.S. \& Ballachev, E.L. (1982). Individual in society. London: McGraw-Hill, Inc.

Lehmiller, J.J. (2014). The psychology of human sexuality. United Kingdom: Wiley Blackwell.

Mahmudah, R. (2012). Hubungan antara intimacy (Sternberg's triangular theory of love) dengan kesiapan menikah pada dewasa muda. Fakultas Psikologi, Universitas Indonesia, Depok.

Marabessy, R. (2009). Perbedaan cinta berdasarkan teori segitiga cinta Sternberg antara wanita dengan pria masa dewasa awal. Fakultas Psikologi, Universitas Gunadarma, Jakarta.

Martopo, D.J. (2000). Sex dan aborsi. Dalam Kumpulan artikel PKBI. Yogyakarta.

Natalia, C. (2013). Dinamika perilaku seksual pranikah remaja Bali. (Studi Kasus tidak dipublikasikan). Fakultas Kedokteran, Universitas Udayana, Denpasar.

Nazir, M. (1988). Metode penelitian. Jakarta: Ghalia Indonesia.

Nofrijal, H. (2011). Generasi berencana. Gorontalo: BKKBN Provinsi Gorontalo.

Notoatmodjo, S. (1997). Ilmu perilaku. Jakarta: Rineka Cipta.

Notoatmodjo, S. (2003). Pendidikan dan perilaku kesehatan. Jakarta: PT. Rineka Cipta.

Olson, D.H. \& Defrain, J. (2003). Marriages and families: Intimacy, strengths, and diversity. United States: McGraw-Hill Higher Education.

Papalia, D.E., Olds, S.W. \& Feldman, R.D. (2004). Human development. Ninth Edition. New York: McGraw-Hill, Inc.

Papalia, D.E., Olds, S.W. \& Feldman, R.D. (2009). Human development (terjemahan: A.K. Anwar). Jakarta: Kencana.

Prasetya, B.E. (2007). Seks pranikah di mata remaja akhir. Jurnal Psikologi, 19 (1)

Prihartini, T., Nuryoto, S. \& Aviatin, T. (2002). Hubungan antara komunikasi efektif tentang seksualitas dalam keluarga dengan sikap remaja awal terhadap pergaulan bebas antar lawan jenis. Jurnal Psikologi, 2, 124-139.

Priyatno, D. (2012). Belajar praktis analisis parametrik dan non parametrik dengan SPSS. Yogyakarta: Gava Media.

Purwanto, H. (1998). Pengantarperilakumanusia. Jakarta: EGC.

Rahyani, K.Y., Utarini, A., Wilopo, S.A. \& Hakimi, M. (2012). Perilaku seks pranikah remaja. Jurnal Kesehatan Masyarakat. 4 (7), 180-185.

Ramanaidoo, S. \& Rathakrishnan, B. (2012). Sikap pelajar institusi pengajian tinggi terhadap hubungan seks sebelum kawin. Jurnal Kemanusiaan, (19)

Rathus, S.A., Nevid, J.S. \& Rathus, L.F. (2009). Human sexuality in a world of diversity. Seventh Edition. Boston: Pearson International Edition.

Riduwan., Rusyana, A. \& Enas. (2013). Cara mudah belajar SPSS 17.0 dan aplikasi statistik penelitian. Bandung: Alfabeta.

Robi'ie, A. (2013). Determinan perilaku seksual berisiko remaja di Indonesia tahun 2010-2012 (Analisis data survei rencana pembangunan jangka menengah nasional remaja BKKBN tahun 2010-2012). Fakultas Kesehatan Masyarakat, Universitas Indonesia, Depok.
Santoso, S. (2005). Mengatasi berbagai masalah statistik dengan SPSS versi 11,5. Jakarta: Elex Media Komputindo.

Santrock, J.W. (2007). Remaja. Edisi Kesebelas. (terjemahan: Widyasinta, B.). Jakarta: Erlangga.

Sarwono, S.W. (2010). Psikologi remaja. Jakarta: Rajawali Pers.

Sarwono, S.W. (2013). Psikologi remaja. Jakarta: Rajawali Pers.

Scanzoni, L.D. \& Scanzoni, J. (1988). Men, women, and change: A sociology of marriage and family. Third Edition. New York: McGraw-Hill Book Company.

Seifert, K.L. \& Hoffnung, R.J. (1987). Child and adolescent development. Boston: Houghton Mifflin Co.

Setyawan, A. (2004). Seks gadis?: Memahami seks membuktikan cinta. Yogyakarta: Galang Press.

Setyorini, A. (2014). Pengaruh konformitas teman sebaya dan intensitas akses pornografi di internet terhadap sikap seksual pranikah. Tesis. Universitas Sebelas Maret, Surakarta.

Shaluhiyah, Z. (2006). Sexual lifestyle and interpersonal relationships of university students in Central Java Indonesia and theirs implication for sexual and reproductive health. Disertasi. Phylosophy in Medical Geography. Exeter.

Soejoeti, S.Z. (2001). Perilaku seks di kalangan remaja dan permasalahannya. Media Litbang Kesehatan, 11 (1).

Soetjiningsih, C.H. (2004). Tumbuh kembang remaja dan permasalahannya. Sagung Seto: Jakarta.

Soetjiningsih, C.H. (2008). Remaja usia 15-18 tahun banyak lakukan perilaku seksual pranikah.Diambil dari web Universitas Gadjah Mada: https://ugm.ac.id/id/berita/551. Diakses pada 15 Maret 2015.

Sternberg, R.J. (1986). A triangular theory of love. Psychological Review, 2 (93), 119-135.

Sternberg, R.J. (1988). The triangle of love: Intimacy, passion, commitment. New York: Basic Books, Inc.

Sternberg, R.J. (1998). Cupids's arrow. United Kingdom: Cambridge University Press.

Sternberg, R.J. (2006). The new psychology of love. New York: Vail-Ballou Press.

Sugiyono. (2012). Statistika untuk penelitian. Bandung: Alfabeta.

Sugiyono. (2014). Metode penelitian kombinasi (mix methods). Bandung: Alfabeta.

Surra, C.A. \& Hughes, D.K. (1997). Commitment processes in accounts of the development of premarital relationship. Journal of Marriage and Family, 59 (1), 5.

Suryabrata, S. (2014). Metodologi penelitian. Jakarta: Rajawali Pers.

Suryani, A. (2004). Perkembangan hubungan perkawinan: Kajian tahap-tahap perkembangan hubungan antar pribadi pada suami-istri Katolik. Jurnal Ilmu Psikologi, 1(2), 113-130.

Susanti, D. \& Martiarini, N. (2009). Hubungan antara pendidikan seks dengan sikap terhadap hubungan seks pranikah pada remaja. JurnalPsikohumanika, II (2), 1-16.

Syamsulhuda, B., Musthofa \& Winarti, F. (2010). Faktor yang mempengaruhi perilaku seks pranikah mahasiswa di Pekalongan tahun 2009-2010. Jurnal Kesehatan Reproduksi, 1 (1), 33-41.

Tambunan, R. (2001). Cinta. Diambil dari e-psikologi: http://www.e psikologi.com/artikel/individual/cinta. Diakses pada 18 Maret 2015. 
Taufik \& Anganthi, N.R.N. (2005). Seksualitas remaja: Perbedaan seksualitas antara remaja yang tidak melakukan hubungan seksual dan remaja yang melakukan hubungan seksual. Jurnal Penelitian Humaniora, 2(6), 115-129.

Taylor, S.E. (2009). Psikologi sosial. Edisi Kedua Belas. Jakarta: Kencana.

Tim Penyusun Kamus Pusat Pembinaan dan Pengembangan Bahasa. (1990). Kamus besar bahasa indonesia. Jakarta: Balai Pustaka.

Wahareni, P.A. (2006). Sikap remaja terhadap perilaku seks bebas ditinjau dari tingkat penalaran moral pada siswa kelas dua SMA Kesatrian 1 Semarang. Skripsi. Universitas Negeri Semarang, Semarang.

Wawan, A. \& Dewi, M. (2011). Teori \& pengukuran: Pengetahuan, sikap dan perilaku manusia. Yogyakarta: Nuha Medika.

Widyastuti, E.S.A. (2009). Personal dan sosial yang mempengaruhi sikap remaja terhadap hubungan seks pranikah. Jurnal Promosi Kesehatan Indonesia, 2 (4), 75-85.

Wulandari, N. (2010). Hubungan antara the big five personality dengan sikap terhadap seks pranikah pada remaja. Fakultas Psikologi, Universitas Gunadarma, Jakarta.

Yudiaatmaja, F. (2013). Analisis regresi dengan menggunakan aplikasi komputer statistik SPSS. Jakarta: Kompas Gramedia Building.

Yuniarti, D. (2007). Pengaruh pendidikan seks terhadap sikap mengenai seks pranikah pada remaja. Fakultas Psikologi, Universitas Gunadarma, Jakarta.

Yunita, S. (2006). Perilaku seksual remaja (Studi kasus kecenderungan perilaku seksual remaja saat berkunjung di sekitar Kafe Lesehan Payung Jl. Pujon Batu Malang). Universitas Muhammadiyah Malang, Malang.

Zakiah, A. (2012). Hubungan antara komponen komitmen dari cinta dengan kesiapan menikah pada dewasa muda. Skripsi. Fakultas Psikologi, Universitas Indonesia, Depok. 